\section{An old fox is trapped: the Staphylococcal Toxic Shock Syndrome in male adult- case report}

Zoran Gluvic ${ }^{1}$, Bojan Mitrovic ${ }^{1}$, Milena Lackovic ${ }^{1}$, Vladimir Samardzic ${ }^{1}$, Dunja Jaksic ${ }^{2}$, Aleksandar Pavlovic ${ }^{2}$, Ratko Tomasevic ${ }^{2}$, Milan Obradovic ${ }^{3}$, Esma R. Isenovic ${ }^{3}$

${ }^{1}$ Zemun Clinical Hospital, Department of Endocrinology, Diabetes and mICU, School of Medicine, University of Belgrade, Serbia

${ }^{2}$ Zemun Clinical Hospital, Department of Gastroenterology and Hepatology, School of Medicine, University of Belgrade, Serbia ${ }^{3}$ Laboratory for radiobiology and molecular genetics, Institute for nuclear sciences "Vinca", University of Belgrade, Serbia

\section{Abstract}

Staphylococcal toxic shock syndrome (STSS) is typically detected in newborns and children but can be seen in adults occasionally. In such a case, it points out usually on some immune system dysfunction. We present a case of a critically-ill adult male with STSS and symptoms and signs of serious systemic infection (hemodynamic instability, acute renal failure, mental confusion). After the completion of applied treatment (antistaphylococcal antimicrobials, hemodialysis, vasopressor, supportive, and symptomatic therapy), complete restoration of presented patients' derangements was achieved. Timely diagnosis and appropriate treatment is the mainstay in the management of STSS in adults.

Key words: vesicle, staphylococcus, toxic shock.

\section{Uhvaćen je stari lisac: Stafilokokni toksični šok sindrom kod odraslog muškarca - prikaz slučaja}

Zoran Gluvić1 ${ }^{1}$, Bojan Mitrović1, Milena Lačković ${ }^{1}$, Vladimir Samardžić ${ }^{1}$, Dunja Jakšić2 ${ }^{2}$, Aleksandar Pavlović ${ }^{2}$ Ratko Tomašević ${ }^{2}$, Milan Obradović ${ }^{3}$, Esma R Isenović ${ }^{3}$

${ }^{1}$ Kliničko bolnički centar Zemun, Služba endokrinologije, dijabetesa $\mathrm{i}$ internističke intenzivne nege, Medicinski fakultet, Univerzitet u Beogradu, Srbija

${ }^{2}$ Kliničko bolnički centar Zemun, Služba gastroenterologije sa hepatologije, Medicinski fakultet, Univerzitet u Beogradu, Srbija ${ }^{3}$ Institut za nuklearne nauke "Vinča", Laboratorija za radiobiologiju i molekularnu genetiku, Univerzitet u Beogradu, Srbija

\section{Apstrakt}

Stafilokokni toksični šok sindrom (STŠS) se obično javlja kod novorođenčadi i dece, ali se povremeno može javiti i kod odraslih. U tom slučaju, obično ukazuje na disfunkciju imunog sistema. Prikazan je slučaj kritično-obolelog odraslog muškarca sa STŠS i simptomima i znacima životno-ugrožavajuće sistemske infekcije (hemodinamska nestabilnost, akutna insuficijencija bubrega, konfuzija). Nakon završenog lečenja (anti-stafilokoni antibiotici, hemodijaliza, vazopresori, suportivna i simptomatska terapija), postignuta je potpuna remisija kod obolelog. Pravovremena dijagnostika i adekvatan tretman je glavno uporište u lečenju STŠS kod odraslih.

Ključne reči: vezikule, stafilokoke, toksični šok.

\title{
Introduction
}

Staphylococcal toxic shock syndrome (STSS) is a rare and serious systemic manifestation of Staphylococcus aureus (SA) colonization and/or infection ${ }^{1}$. Produced SA-exotoxins, commonly associated with negative cultures of blood and cerebrospinal fluid, are responsible for the massive systemic immune and inflammatory response, which can cause life-threatening systemic clinical presentation ${ }^{2}$. Some other factors, like the presence of chronic heart and pulmonary diseases, surgery or postpartum infection, vaginal tampon use, infection with Influenza A or Varicella Zoster Virus, could contribute to STSS development ${ }^{1,2}$. The annual incidence of STSS ranges from 1.5-11 per 100.000 people $^{3,4}$. The diagnostic criteria are enlisted in Appendix 1. 
1. Fever: temperature $>38.8^{\circ} \mathrm{C}$

2. Rash: diffuse macular erythroderma

3. Desquamation: 1 to 2 weeks after onset of rash

4. Hypotension: systolic blood pressure $<90 \mathrm{~mm}$ of Mercury for adults or $<5$ th $\%$ by age for children aged $<16$ years

5. Multisystem involvement ( $\geq 3$ of the following organ systems):

- Gastrointestinal: vomiting or diarrhea

- Muscular: myalgia or creatine phosphokinase level at least twice the upper limit of normal

- Mucous membrane: vaginal, oropharyngeal, or conjunctival hyperemia

- Renal: blood urea nitrogen or creatinine at least twice the upper limit of normal for laboratory or urinary sediment with pyuria ( $\geq 5$ leukocytes per high-power field) in the absence of urinary tract infection

- Hepatic: total bilirubin, alanine aminotransferase enzyme, or aspartate aminotransferase enzyme levels at least twice the upper limit of normal for laboratory

- Hematologic: platelets $<100.000 / \mathrm{mm}^{3}$

- Central nervous system: disorientation or altered mental status

- Laboratory findings

\# Blood or cerebrospinal fluid cultures blood culture may be positive for SA

\# Negative serologies for Rocky Mountain spotted fever, leptospirosis, or measles

Appendix 1. STSS diagnostic criteria ${ }^{5}$

If 4 of the 5 criteria are fulfilled along with laboratory criteria, the STSS diagnosis is probable; if 5 of 5 criteria are fulfilled along with laboratory criteria, the STSS diagnosis is confirmed ${ }^{5}$. The management of STSS is conducted with appropriate antimicrobials, resuscitation, and supportive therapy. Despite such aggressive management, the overall mortality rate due to STSS is about $4.1 \%$ and is much lower than in Streptococcal Toxic Shock Syndrome ${ }^{1,6}$.

We present a case of an adult 56 years old male, who is hospitalized because of dyspnea, fever, and a macular rash of neck and trunk, with the development of progressive multiorgan failure.

\section{Case report}

Male, 56 years old patient, was admitted to hospital because of dyspnea, fever $\left(>39^{\circ} \mathrm{C}\right)$, and sore throat. The complaints began two days before admission. Patient reported appendectomy in childhood and no chronic disease.

On examination, he was aware but confused, febrile $\left(39,7^{\circ} \mathrm{C}\right)$, with the presence of dyspnea, central and peripheral cyanosis, central obesity, macular erythroderma of neck and trunk regions, and herpetic vesicles of the upper lip and right nostril. Results of the neurological examination were normal. Chest auscultation revealed bilateral basal inspiratory crackles. Heart action was rhythmic, with dull sounds and no murmurs, pulse rate 130/min., blood pressure $80 / 60 \mathrm{~mm}$ of Mercury. Abdominal examination was normal. The signs of chronic venous insufficiency were found in both pretibial regions

On day 2, the macular rash disseminated to axillae, forearms, and thighs, with distinguishing of clear liquidfilled blisters. On the next day, the majority of blisters have fused and broken shortly after, with discerning of epidermolysis and reddish surface under. The culture of blister content revealed vancomycin sensitive Staph. On day 5, yellow and black parts of damaged epidermis became drier and started to detach. On day 10, the signs of re-epithelization were registered and almost entire restoration of dermal changes soon after (Figures 1-3). On day 14, only erythematous skin persisted on the sites of body pressure. 


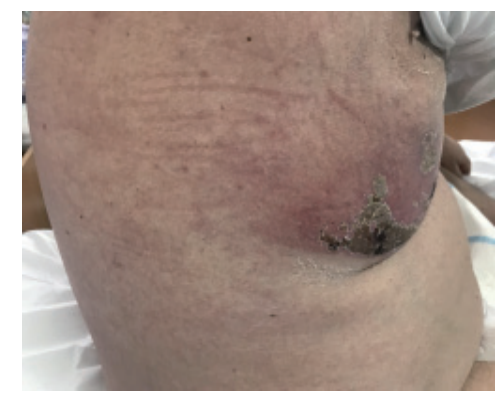

Figure 1. Erythematous surface on the lateral trunk with detached epidermis

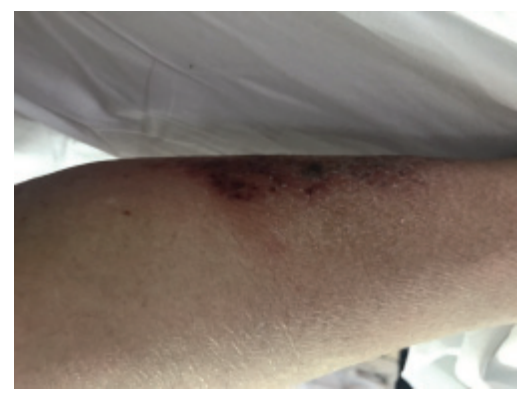

Figure 2. Desquamation and remnants of detached epidermis of forearm skin

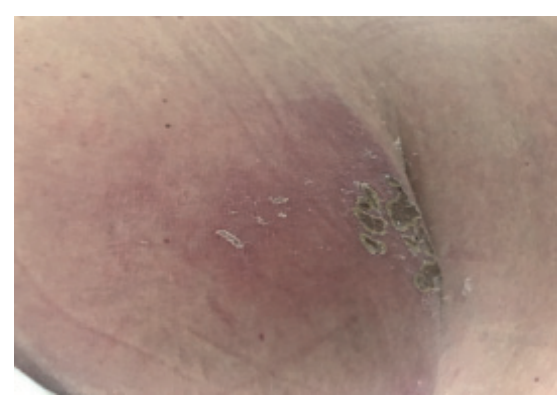

Figure 3. Damaged epidermis of gluteal region

\section{Material and methods}

Blood analyses were performed by DxC 800 and DXI-600 devices, Beckman Coulter Inc., USA. Coagulation testing was performed with IL ELITE PRO ${ }^{\circledR}$, ACL $300 \AA$ and ROTEM delta analyzers, Instrumentation Laboratory, Werfen, USA. Abdominal ultrasound was performed by Toshiba Xario, Japan. Chest and abdominal X-ray was performed by Agfa DX-D100+, Belgium. Focus V-Scan Heart Ultrasound was performed by Vscan Extend Handheld Ultrasound, General Electric Healthcare, USA.

\section{Results}

Laboratory findings showed moderately accelerated erythrocyte sedimentation rate, leukocytosis, mild hyperglycemia, overall hypoproteinemia, hypocholesterolemia, elevated creatin-kinase (CK) and CK-MB fraction with mild increase in troponin level, hyponatremia and hypocalcemia, with significant increase in blood urea nitrogen and creatinine levels as well as metabolic acidosis in blood gases [pH 7.31 (7.35-7.45), pCO2 29 (25-45) mm of Mercury, pO2 83 (80-100) mm of Mercury, SO2 95 (>92) \%, HCO3- 14.6 (21-30) mmol/L]. C-reactive protein was significantly elevated, as well as some inflammatory markers [Procalcitonin $8.89(<0.5)$ $\mathrm{ng} / \mathrm{mL}, \mathrm{D}$ dimer $2500(0-570) \mathrm{ng} / \mathrm{mL}$. Urinalysis showed microhematuria and qualitative proteinuria (2+). Coagulation abnormalities are not detected (Prothrombin time, International Normalized Ratio, Rotational thromboelastometry). Thyroid function test revealed no thyroid dysfunction [thyroid stimulation hormoneTSH 1.04 (0.4-4.0) $\mathrm{mIU} / \mathrm{ml}$; free thyroxine-fT4 7.95 (7.8-14.3) pmol/L]. Blood-transmitted viruses were not detected and immunoserology was negative (Antistreptolysin, Rheumatoid Factor, C3 component of complement, Circulated Immune Complexes, Anti-neutrophil cytoplasmic antibodies- ANCA, Antinuclear antibodies-Hep2 cell culture, antimyeloperoxidase/proteinase 3 or p/cANCA antibodies). The cultures of throat/nose swabs, urine, blood, and stool were negative. Detection of Clostridium difficile was negative. Other laboratory findings on admission and at discharge are shown in Table 1.

\begin{tabular}{|l|c|c|c|}
\hline \multicolumn{1}{|c|}{ Analysis } & On admission & At discharge & Reference values \\
\hline White blood cells (x10//L) & 20.2 & 12.1 & $4.4-11.5$ \\
\hline Red blood cells (x10 $\mathbf{1 2} / \mathbf{L})$ & 4.08 & 3.61 & $4.20-5.40$ \\
\hline Hemoglobin (g/L) & 122 & 107 & $123-153$ \\
\hline Hematocrite (L/L) & .37 & .33 & $0.35-0.47$ \\
\hline Platelets (x10/L) & 140 & 239 & $140-400$ \\
\hline $\begin{array}{l}\text { Erythrocyte sedimentation rate } \\
\text { (mm/hr) }\end{array}$ & 60 & 20 & $\leq 25$ \\
\hline Glycaemia (mmol/L) & 8.6 & 4.8 & $3.9-6.1$ \\
\hline Overall proteins (g/L) & 50 & 58 & $35.0-81.0$ \\
\hline Albumine (g/L) & 24 & 30 & \\
\hline
\end{tabular}




\begin{tabular}{|l|c|c|c|}
\hline Triglycerides (mmol/L) & 3.66 & 1.41 & $<1.95$ \\
\hline Cholesterol (mmol/L) & 2.74 & 3.12 & $3.4-5.8$ \\
\hline C-reactive protein (mg/L) & 239.8 & 14.4 & $0.0-7.0$ \\
\hline AST (U/L) & 75 & 75 & $<37$ \\
\hline ALT (U/L) & 30 & 52 & $<43$ \\
\hline Creatine-kinase (U/L) & 3201 & 598 & $<195$ \\
\hline Creatine-kinase MB (U/L) & 77 & 34 & 42.9 \\
\hline Troponin HS (pg/mL) & 49.4 & 42.6 & $138-149$ \\
\hline Sodium (mmol/L) & 127 & 137 & $4.0-5.0$ \\
\hline Potassium (mmol/L) & 3.8 & 3.8 & $2.2-2.7$ \\
\hline Calcium (mmol/L) & 1.74 & 1.97 & $2.5-7.5$ \\
\hline Blood Urea Nitrogen (mmol/L) & 24.2 & 7.6 & $44-133$ \\
\hline Creatinine (micmol/L) & 548 & 82 & \\
\hline
\end{tabular}

Table 1. Laboratory findings on admission and at discharge

Imaging procedures. After hospital admission, chest- and abdominal X-ray showed no pathological findings. Focus V-Scan Heart Ultrasound detected both right heart chambers mild dilation, with preserved contractility and with no indirect signs of acute pulmonary embolism. Additionally, no pericardial effusion and valves vegetation were detected. A multidisciplinary team made a decision to delay the performance of high-risk computed tomography pulmonary angiography because of acute renal failure and problems presented with emergency hemodialysis access. An abdominal ultrasound performed on day 3 detected the hyperechoic liver, enlarged kidneys (right: $137 / 25 \mathrm{~mm}$, left: $140 / 28 \mathrm{~mm}$ ) and spleen $(130 \mathrm{~mm})$, and no ascites and enlarged lymph nodes. Dermatologist consultant (day 14) suggested topical antiviral and antimicrobial treatment along with already applied systemic treatment.

The patient was managed with hemodialysis (acute renal failure possible due to septic shock), fresh frozen plasma and blood transfusions, vasopressor, antimicrobials (vancomycin, meropenem, metronidazole) and other supportive and symptomatic treatment. The results of pathological biochemistry repeated at discharge (day 14) were improved as well as abdominal ultrasound revealed restoration of previously enlarged organs (kidneys and spleen).

\section{Discussion}

Staphylococcus aureus is gram-positive pathogen capable of producing a variety of bacterial exotoxins, including a family of toxins known as superantigens (enterotoxins, epidermolytic toxins, toxic shock syndrome toxin-TSST-1 $)^{6,7,8}$. The isolates of SA can encode one or more superantigens ${ }^{9,10}$. Among them, TSST-1 can individually cause STSS ${ }^{11}$. Superantigens are being presented by antigen-presenting cells and induce excessive polyclonal $\mathrm{T}$ and $\mathrm{B}$ cell proliferation and activity and blast of cytokine production, which leads to STSS $^{7,8,12}$. Depending on cycle, STSS is historically divided into menstrual and non-menstrual form. The menstrual form of STSS is associated with vaginal tampon use, while the non-menstrual form can be caused by focal infections, burns, soft tissue injuries, postsurgical and postpartum wounds and infections $6,13,14$. The prevalence of antibodies against TSST-1 is over $90 \%$ in adults, but in children is significantly lower ${ }^{12,15}$. Mucosal colonization with SA that produces TSST-1 is responsible for anti-TSST-1 antibody production. Such antibody production should be the explanation of seldom presence of STSS in adults ${ }^{12,16}$. STSS is a life-threatening condition. The patients should be aggressively managed according to the current sepsis guidelines ${ }^{12,17}$. Antibiotics should include a penicillinase-resistant penicillins, cephalosporins, or vancomycin along with either clindamycin or linezolid ${ }^{14}$. Despite antimicrobial and other resuscitation therapy, the overall mortality rates are high. The introduction of immunotherapy, such as monoclonal antitoxin antibodies, seems to be a promising strategy in regard to improving patients' management8.

It is of great importance to emphasize the appropriate and fast revealing of STSS. Its course can be very unpredictable, so any delay regarding timely diagnosis can be hazardous. Despite the fact that it more 
frequently occurs in children, the clinician must always bear in mind about its occurrence in adults, especially in those with somehow impaired immunity. As we reported in our case, the course of disease determines the management plan and performance of procedures.

\section{Conclusion}

It is of cumbersome significance to diagnose and treat STSS timely ${ }^{14}$. The presence of STSS in adults sometimes reveals some condition or disease that disturbs the host's immune system.

\section{References}

1. Cambria A, West L. Lethal rashes. Physician Assistant Clinics 2017; 2(3):371-84.

2. Asano K, Narita K, Hirose S, Nakane A. Contribution of toxic shock syndrome toxin-1 to systemic inflammation investigated by a mouse model of cervicovaginal infection with staphylococcus aureus. Med Microbiol Immunol 2018; 207:297-306.

3. Hoge CW, Schwartz B, Talkington DF, Breiman RF, MacNeill EM, Englender SJ. The changing epidemiology of invasive group A streptococcal infections and the emergence of streptococcal toxic shock-like syndrome. A retrospective population-based study. JAMA 1993; 269(3):384-9.

4. Strom MA, Hsu DY, Silverberg JI. Prevalence, comorbidities and mortality of toxic shock syndrome in children and adults in the USA. Microbiol Immunol 2017; 61(11):463-73.

5. http://wwwn.cdc.gov/nndss/conditions/toxic-shock-syndrome-otherthan-streptococcal/case-definition/2011/

6. Török ME, Day NPJ. Staphylococcal and streptococcal infections. Medicine 2014; 42(1):1-7.

7. Kotb M. Bacterial pyrogenic exotoxins as superantigens. Clin Microbiol Rev 1995; 8:411-26.

8. Aguilar JA, Varshney AK, Pechuan X, Dutta K, Nosanchuk JD, Fries BC. Monoclonal antibodies protect from Staphylococcal Enterotoxin K (SEK) induced toxic shock and sepsis by USA300 Staphylococcus aureus. Virulence 2017; 8:741-50.

9. Varshney AK, Mediavilla JR, Robiou N, Guh A, Wang X, Gialanella P et al. Diverse enterotoxin gene profiles among clonal complexes of Staphylococcus aureus isolates from the Bronx, New York. App Envir Microbiol 2009; 75:6839-49.

10. Brosnahan AJ, Schlievert PM. Gram-positive bacterial superantigen outside-in signaling causes toxic shock syndrome. FEBS J 2011; 278:4649-67.

11. Li J, Yang J, Lu YW, Wu S, Wang MR, Zhu JM. Possible Role of Staphylococcal Enterotoxin B in the Pathogenesis of Autoimmune Diseases. Viral Immunol 2015; 7:354-9.

12. Chuang YY, Huang YC, Lin TY. Toxic shock syndrome in children: epidemiology, pathogenesis, and management. Paediatr Drugs 2005; 7:11-25.

13. Low DE. Toxic Shock Syndrome Major Advances in Pathogenesis, But Not Treatment. Crit Care Clin 2013; 29:651-75.

14. Gottlieb M, Long B, Koyfman A. The evaluation and management of toxic shock syndrome in the emergency department: a review of the literature. The Journal of Emergency Medicine 2018; 54(6):807-14.

15. Vergeront JM, Stolz SJ, Crass BA, Nelson DB, Davis JP, Bergdoll MS. Prevalence of serum antibody to staphylococcal enterotoxin F among Wisconsin residents: implications for toxic-shock syndrome. J Infect Dis 1983;148:692-8.

16. Parsonnet J, Hansmann MA, Delaney ML, Modern PA, DuBois AM, Wieland-Alter W. Prevalence of toxic shock syndrome toxin 1-producing Staphylococcus aureus and the presence of antibodies to this superantigen in menstruating women. J Clin Microbiol 2005; 43:4628-34.

17. Rhodes A, Evans LE, Alhazzani W, Levy MM, Antonelli M, Ferrer R, et al. Surviving Sepsis Campaign: international guidelines for management of sepsis and septic shock: 2016. Crit Care Med 2017; 45(3):486-552.

\section{Zahvalnica}

Rad je nastao u kolaboraciji Klinike za internu medicinu KBC Zemun i Laboratorije za radiobiologiju i molekularnu genetiku Instituta za nuklearne nauke Vinča, kao deo projekta Ministarstva za nauku i tehnologiju br. 173033 (E.R.I.).

Corresponding Author: Zoran Gluvic MD, PhD, Zemun Clinical Hospital, Department of Endocrinology, Diabetes and mICU, School of Medicine, University of Belgrade, Serbia E-mail: zorangluvic@yahoo.com,Office: +381-11-3772 715, Cell: +381-69-1109 019 